\title{
Efficient use of water and nutrients in irrigated cropping systems in the Alqueva region
}

\author{
Eficiencia en el uso de agua y nutrientes en sistemas de cultivo de regadio en la región de \\ Alqueva \\ Eficiência no uso da água e dos nutrientes em sistemas culturais de regadio na região de \\ Alqueva
}

\section{AUTHORS \\ Tomaz A. ${ }^{\circledR, 1,2}$ \\ atomaz@ipbeja.pt}

Patanita M. ${ }^{1,2}$

Guerreiro I. ${ }^{1}$

Dôres J. ${ }^{1}$

Boteta L. ${ }^{3}$

Ferro Palma J. ${ }^{1}$

@ Corresponding Author

${ }^{1}$ Departamento de Biociências, Escola Superior Agrária - Instituto Politécnico de Beja. R. Pedro Soares s/n. 7800295 Beja, Portugal.

${ }^{2}$ GeoBioTec, Universidade Nova de Lisboa. Campus da Caparica. 2829-516

Caparica, Portugal.

${ }^{3}$ Centro Operativo e de Tecnologia de Regadio. Quinta da Saúde, Apartado 354. 7801-904 Beja, Portugal.
Received: 07.02.2017 | Revised: 31.10.2017 | Accepted: 11.01.2018

\section{ABSTRACT}

In the region of Alentejo, Southern Portugal, as a consequence of the implementation of the Alqueva global irrigation system, agriculture intensification is challenging the sustainability of the farming systems. The demand for water and for fertilizers is increasing but so is the demand for water use efficiency (WUE) and for nutrient use efficiency (NUE). Increasing resource-use efficiency while reducing yield gaps can be addressed by suitable agricultural management practices, as in the case of crop rotations. Based on a demonstration project carried out in two farms located in Baixo Alentejo, within the Alqueva irrigation network, soil fertility parameters, WUE and NUE (for nitrogen, phosphorus and potassium) were studied in three maize-based cropping systems: a maize monoculture (M-M) and two rotations, barley+maize-barley (BM-B) and sunflower-barley+maize (S-BM). The total soil organic matter content increased in the two rotations, an important observation especially in soils with low organic content. The final balance of extractable phosphorus and potassium was positive in the BM-B rotation. Water use efficiency values point to a less balanced performance of the S-BM rotation. The WUE and the nitrogen NUE in the different crops and rotations followed a similar pattern. The M-M and BM-B crop successions showed the best indicators of NUE for nitrogen and phosphorus. In all the cropping systems, the potassium NUE was low, suggesting the need to carefully equate the additions of this nutrient by fertilization.

\section{RESUMEN}

En la región de Alentejo, en el Sur de Portugal, como resultado de la ejecución del sistema global de riego de Alqueva, la intensificación de la agricultura es un reto para la sostenibilidad de los sistemas de producción agricola. La demanda de agua y fertilizantes está aumentando pero lo mismo ocurre con la demanda en el uso eficiente del agua (WUE) y nutrientes (NUE). El aumento de la eficiencia en el uso de los recursos acompañado de mejoras en la productividad se puede lograr a través de prácticas agronómicas apropiadas, tales como la rotación de cultivos. Con base en un proyecto de demostración llevado a cabo en dos fincas ubicadas en el Baixo Alentejo, en la zona de riego de Alqueva, se analizaron los parámetros de fertilidad del suelo, la WUE y la NUE (del nitrógeno, del fósforo $y$ del potasio) en tres sistemas de cultivos basados en el maiz: un monocultivo de maiz ( $M-M)$ y dos rotaciones, cebada+maiz-cebada (BM-B) y girasol-cebada+maiz (S-BM). El contenido de materia orgánica total del suelo se incrementó en dos rotaciones, una observación importante especialmente en suelos con bajo contenido orgánico. El balance final de fósforo y potasio extractable fue positivo en la rotación BM-B. Los valores de WUE apuntan a un comportamiento menos equilibrado de la rotación S-BM. La WUE y la NUE del nitrógeno en los distintas cultivos 
y rotaciones siguieron una tendencia similar. Las secuencias de cultivos $M-M$ y $B M-B$ mostraron los mejores indicadores de NUE para nitrógeno y fósforo. En todos los sistemas de cultivo la NUE del potasio fue baja, lo que sugiere la necesidad de abordar de forma cuidadosa las aplicaciones de este nutriente por fertilización.

\section{RESUMO}

Na região do Alentejo, no Sul de Portugal, como resultado da implementação do sistema global de rega de Alqueva, a intensificação da agricultura constitui um desafio à sustentabilidade dos sistemas de produção agrícola. A procura de água e de fertilizantes está a aumentar mas o mesmo acontece com a eficiência no uso da água (WUE) e dos nutrientes (NUE). O aumento na eficiencia de uso dos recursos acompanhado de ganhos de produtividade pode ser alcançado através de práticas agronómicas adequadas, como é o caso das rotações culturais. Com base num projeto de demonstração realizado em duas explorações agricolas localizadas no Baixo Alentejo, no perímetro de rega de Alqueva, analisaram-se os parâmetros de fertilidade do solo, a WUE e a NUE (do azoto, do fósforo e do potássio) em três sucessões culturais baseadas em milho: uma monocultura de milho ( $M-M)$ e duas rotaçôes, cevada+milhocevada (BM-B) e girassol-cevada+milho (S-BM). O teor de matéria orgânica total do solo aumentou nas duas rotaçôes, uma observação importante principalmente em solos com baixos teores de matéria orgânica. O balanço final de fósforo e potássio extraíveis foi positivo na rotação $B M-B$. Os valores de WUE apontam para um desempenho menos equilibrado da rotação $S-B M$. A WUE e a NUE do nitrogénio nas várias culturas e rotações seguiram um padrão semelhante. As sucessões culturais $M-M e B M-B$ apresentaram os melhores indicadores de NUE em relação ao nitrogénio e ao fósforo. Em todas as sucessões culturais, a NUE do potássio foi baixa, sugerindo a necessidade de equacionar de forma cuidada as aplicaçôes deste nutriente por fertilização.

\section{Introduction}

Southern Portugal agriculture is conditioned by a Mediterranean climate, with a hot and dry summer and a great seasonal and interannual variability in the distribution of precipitation and evapotranspiration, which results in areas with a rather irregular hydrologic cycle and more susceptible to drought. Faced with this reality in the last few years, due to the development of the irrigation network of the Alqueva Multi-Purpose Development (EFMA - Empreendimento para Fins Múltiplos de Alqueva) in the Southern Portugal region of Alentejo, farmers are increasingly adopting irrigation and predictably using more mineral fertilizers. This agriculture intensification is progressively changing the farming model and the agricultural landscape of the region, which makes it vital to adopt suitable strategies and agronomic practices that are both productive and sustainable.

Maize (Zea mays L.), barley (Hordeum vulgare L.) and sunflower (Helianthus annuus L.) are among the most cultivated field crops in Alentejo. According to INE (2017), approximately $46 \%$ of the 2016 Portuguese grain maize was produced in Alentejo. In the case of barley and sunflower, Alentejo is also the largest Portuguese producer region, representing, respectively, $93 \%$ and $90 \%$ of 2016 total production of these crops. Average 2016 crop yields in Alentejo were 12.9 t/ha for maize, $2.4 \mathrm{t} / \mathrm{ha}$ for barley and 1.4 t/ha for sunflower (INE 2017). Due to the predominance of more intensive irrigated maize-based cropping systems in Alentejo, the average maize yield in this region was higher than the whole Portuguese average - about 8.0 t/ha - which is ranked 15 th in terms of grain maize yields in the 28 European Union Member States (Eurostat 2017). 
Yield improvement, along with increased resource-use efficiency, depends on proper water management but the choice of the best crops and cultivars, adapted to local environmental conditions, the careful selection of the farming operations and the proper cropping systems also contribute in a decisive way. For a given set of climatic and soil conditions, economic and environmental sustainability can be achieved by the use of crop rotations, depending on the correct choice of crops, and the appropriate supply of water and nutrients (López-Fando and Almendros 1995; Eltz and Norton 1997; Sainju et al. 2011; Pereira et al. 2012).

The crop water status influences nutrient use efficiency (NUE) and, at the same time, the nutritional status of the plants can influence water use efficiency (WUE) (Albrizio et al. 2010; Fixen et al. 2015; Hernández et al. 2015). Proper nitrogen fertilization promotes an expansion of the leaf area, an increase of the vegetation cover, an increase in transpiration and a reduction in evaporation, thus enhancing evapotranspiration efficiency. Higher phosphorus availability for plants favors root development, thus contributing to the increase in available water. Because of its role as an osmotic regulator, potassium determines the extraction of water by the roots, its transport to other parts of the plant and the management of water in the plant itself, reducing water losses through transpiration (Grzebisz et al. 2013; Sharma et al. 2015). Water and nutrient use efficiency of crops submitted to different levels of irrigation and/or fertilization has been studied by several researchers, such as Nevens and Reheul (2001), Di Paolo and Rinaldi (2008), Albrizio et al. (2010), Morell et al. (2011), Langeroodi et al. (2014) and Kresović et al. (2016). These studies, performed on test plots, focused specifically on crops such as maize, durum wheat (Triticum durum Desf.), barley and sunflower, and not their on rotations.

Taking the above into account, this study has the following objectives: (i) to assess the soil fertility parameters evolution for each crop and cropping system studied; (ii) to analyze the use efficiency of water, irrigation water, and nitrogen, phosphorus and potassium available for each crop and cropping system studied.

\section{Materials and methods}

\subsection{Site description}

The study was carried out during 2012/2013 and $2013 / 2014$ on a maize monoculture (M-M) (Lat: $37^{\circ} 58^{\prime} 27.44^{\prime \prime} \mathrm{N}$; Long: $8^{\circ} 8^{\prime} 38.78^{\prime \prime} \mathrm{W}$ ), a 2-year barley with maize - barley rotation (BM-B)(Lat: $37^{\circ} 58^{\prime} 11.43^{\prime \prime} \mathrm{N}$; Long: 8 $8^{\prime} 54.02 " \mathrm{~W}$ ), and a 2-year sunflower - barley with maize rotation (S-BM) (Lat: $37^{\circ} 57^{\prime} 46.94 " \mathrm{~N}$; Long: $\left.7^{\circ} 30^{\prime} 4.73^{\prime \prime} \mathrm{W}\right)$. The first two cropping systems were installed in a private farm located in the municipality of Aljustrel and the last at a private farm located in the municipality of Serpa, both sited in the District of Beja, within the Alqueva irrigation network (South of Portugal).

Meteorological data were recorded in two automatic weather stations located near the farms, belonging to SAGRA (Sistema Agrometeorológico para a Gestão da Rega no Alentejo), an agro-meteorological network support service to farmers in the Alentejo region (COTR 2016a). According to Köppen classification, the climate in the region is Mediterranean or Temperate with hot and dry summer (Csa). The main climatic variables for 2012, 2013 and 2014 and long-term means (1981-2010) are given in Table 1 (COTR 2016a; IPMA 2016).

The soils of the studied plots are Chromic Cambisols $(\mathrm{Bc})$, with a silt loam texture, in the case of the M-M and BM-B, and Vertic Cambisols (Bv) (IUSS Working Group WRB 2015), with a clay loam texture in the S-BM area.

Coarse fragments and soil texture were obtained by $\leq 2 \mathrm{~mm}$-sieving and particle size analysis (pipette method), respectively, performed on samples from the $0-30 \mathrm{~cm}$ layer of the soil profile (Table 2). Bulk density was estimated by weighing the soil that filled a container of known volume. Soil moisture values at $33 \mathrm{kPa}$ tension and $1500 \mathrm{kPa}$ tension were determined using pressure and ceramic plates (Soil moisture Equipment Corp.). 
Table 1. Long-term (1981-2010) and 2012, 2013 and 2014 main climatic variables of the experimental sites (Beja, Aljustrel and Serpa)

\begin{tabular}{lcccc} 
Location & Year & $\mathbf{T}_{\text {mean }}\left({ }^{\circ} \mathbf{C}\right)$ & $\mathbf{P}(\mathbf{m m})$ & $\mathbf{E T}_{0}(\mathbf{m m})$ \\
\hline Beja & Long-term $(1981-2010)$ & 16.9 & 558 & Not available \\
\hline Aljustrel & 2012 & 15.8 & 556 & 1194 \\
\hline & 2013 & 16.2 & 499 & 1195 \\
\hline Serpa & 2014 & 16.4 & 634 & 1174 \\
\hline & 2012 & 16.6 & 502 & 1225 \\
\hline & 2013 & 16.8 & 447 & 1216 \\
\hline
\end{tabular}

$\mathrm{T}_{\text {mean }}$ - mean annual temperature; $\mathrm{P}(\mathrm{mm})$ - annual rainfall; $\mathrm{ET}_{0}(\mathrm{~mm})$ - mean annual reference evapotranspiration.

Table 2. Soil physical properties (0-30 cm layer)

\begin{tabular}{|c|c|c|c|c|c|c|c|c|c|c|}
\hline $\begin{array}{l}\text { Cropping } \\
\text { system }\end{array}$ & $\begin{array}{c}\text { Coarse } \\
\text { fragments } \\
(\mathrm{g} / \mathrm{kg})\end{array}$ & $\begin{array}{c}\text { Coarse } \\
\text { sand } \\
(\mathrm{g} / \mathrm{kg})\end{array}$ & $\begin{array}{l}\text { Fine sand } \\
\quad(\mathrm{g} / \mathrm{kg})\end{array}$ & Silt (g/kg) & $\begin{array}{l}\text { Clay } \\
(\mathrm{g} / \mathrm{kg})\end{array}$ & $\begin{array}{l}\text { Textural } \\
\text { class }\end{array}$ & $\begin{array}{c}\text { Bulk } \\
\text { density } \\
\left(\mathrm{g} / \mathrm{cm}^{3}\right)\end{array}$ & $\begin{array}{c}\text { Soil } \\
\text { water } \\
\text { content } \\
\text { at } 33 \mathrm{kPa} \\
(\mathrm{C} \mathrm{m}, \%)\end{array}$ & $\begin{array}{c}\text { Soil } \\
\text { water } \\
\text { content } \\
\text { at } 1500 \\
\mathrm{kPa} \\
((\mathrm{)}, \%)\end{array}$ & $\begin{array}{c}\text { Available } \\
\text { water } \\
\text { (() } \mathrm{m}, \%)\end{array}$ \\
\hline M-M & 759 & 177 & 205 & 479 & 124 & SL & 1.3 & 30.62 & 14.74 & 15.88 \\
\hline BM-B & 735 & 190 & 212 & 453 & 128 & SL & 1.3 & 27.02 & 14.31 & 12.71 \\
\hline S-BM & 756 & 189 & 249 & 279 & 273 & $\mathrm{CL}$ & 1.2 & 26.44 & 13.91 & 12.53 \\
\hline
\end{tabular}

M-M - maize monoculture; BM-B -barley+maize-barley rotation; S-BM -sunflower-barley+maize rotation; SL - Silt loam; CL - Clay loam.

\subsection{Soil fertility parameters}

The evaluation of soil fertility took place in the year prior to the sowing of the first crops and before the sowing of each crop, based on the determination of the following parameters: total organic matter content (Walkley-Black method) (Walkley and Black 1934); $\mathrm{pH}\left(\mathrm{H}_{2} \mathrm{O}\right)$ (potentiometer); extractable phosphorus and potassium contents (Egner-Riehm method) (Egner et al. 1960). For this purpose, soil samples were collected in the topsoil, from 0 to $30 \mathrm{~cm}$ deep, using an open end soil probe, on four dates in the case of the rotations and three dates in the case of the monoculture.

\subsection{Agricultural practices}

The precedent crops in M-M, BM-B and S-BM were maize, sunflower and soft wheat (Triticum aestivum L.), respectively. Soils were conventionally tilled, as commonly performed by the farmers, with the exception of the maize crops in rotation as second crop, planted shortly after barley harvest, that were directly seeded on the barley stubble. Solid and water-soluble fertilizers were used. The former were NPK formulations, applied at sowing date using localized placement and broadcasting in all the crops; the latter were nitrogen fertilizers applied over the crop cycle through irrigation water, in the case of maize and sunflower, and using broadcast spreaders in barley. 
The main crop management data are described in Table 3.

2.4. Irrigation requirements and irrigation systems

Crop evapotranspiration (ETc) was estimated using the MOGRA (Modelo de Gestão da Rega para o Alentejo) model (Mendes et al. 2014; COTR 2016b), developed as an on-line support tool for farmers. This model is a daily soil water balance model that uses information from the SAGRA network and the specific information for each monitored crop (like location, soil, cropping system, irrigation technology, sowing date or beginning of crop production cycle). It provides real-time irrigation schedules as well as the calculation of the optimal crop water requirements based on the FAO methodology for computing crop water requirements (Allen et al. 1998). Seasonal ETc obtained with MOGRA and seasonal precipitation data registered in the automatic weather stations are shown in Table 4. The applied irrigation volumes were recorded with automatic udometers (Datataker DT5).
The soil water content was monitored hourly with non-calibrated in situ capacitance probes (EnviroSCAN, Sentek Technologies), with the main objective of defining irrigation opportunity. All crops were irrigated by center-pivots with spray-type sprinklers mounted on drop tubes. Flow rates per unit area in M-M, BM-B and S-BM center pivots were $1.4 \mathrm{l} / \mathrm{s} / \mathrm{ha}, 1.2 \mathrm{l} / \mathrm{s} / \mathrm{ha}$ and 1.3 $\mathrm{I} / \mathrm{s} / \mathrm{ha}$, respectively. Pressures at the pivot center were $495 \mathrm{kPa}, 459 \mathrm{kPa}$ and $540 \mathrm{kPa}$, for M-M, BM-B and S-BM center pivots, respectively. At the end of the center pivots, pressure values reduced $50 \%$ in the $\mathrm{M}-\mathrm{M}$ pivot, and $44 \%$ in both the BM-B and S-BM pivots. Pressurized irrigation water is supplied on request from hydrants by the public company EDIA (Empresa de Desenvolvimento e Infra-Estruturas de Alqueva, $S A$ ), the EFMA administrator.

2.5. Water use - yield and nutrients use - yield relationships

To evaluate yield water use efficiency the following indicators were used (Howell 2001; Zwart and Bastiaanssen 2004; Dağdelen et al.

Table 3. Main crop management data

\begin{tabular}{|c|c|c|c|c|c|c|c|c|c|c|}
\hline $\begin{array}{l}\text { Cropping } \\
\text { system }\end{array}$ & $\begin{array}{c}\text { Crop } \\
\text { (variety) }\end{array}$ & $\begin{array}{l}\text { Area } \\
\text { (ha) }\end{array}$ & $\begin{array}{l}\text { Sowing date } \\
\text { (dd/mm/yy) }\end{array}$ & $\begin{array}{l}\text { IW } \\
(\mathrm{mm})\end{array}$ & $\begin{array}{c}\text { First } \\
\text { irrigation } \\
\text { date } \\
\text { (dd/mm/yy) }\end{array}$ & $\begin{array}{c}\text { Last } \\
\text { irrigation } \\
\text { date } \\
\text { (dd/mm/yy) }\end{array}$ & $\begin{array}{c}\mathrm{N} \\
\text { (kg N/ha) }\end{array}$ & $\underset{\left(k g \mathrm{P}_{2} \mathrm{O}_{5} / \mathrm{ha}\right)}{\mathrm{P}}$ & $\begin{array}{c}\mathrm{K} \\
\left(\mathrm{kg} \mathrm{K}_{2} \mathrm{O} / \mathrm{ha}\right)\end{array}$ & $\begin{array}{c}\text { Harvest } \\
\text { date } \\
\text { (dd/mm/yy) }\end{array}$ \\
\hline \multirow[t]{2}{*}{ M-M } & $\begin{array}{c}\text { Maize } \\
(P R 33 D 48)\end{array}$ & 34 & $05 / 05 / 13$ & 697 & $06 / 05 / 13$ & $26 / 09 / 13$ & 359.3 & 94.7 & 150.0 & $15 / 10 / 13$ \\
\hline & $\begin{array}{l}\text { Maize } \\
(P 1758)\end{array}$ & 46 & $28 / 04 / 14$ & 626 & $30 / 04 / 14$ & $13 / 09 / 14$ & 359.3 & 94.7 & 150.0 & $20 / 10 / 14$ \\
\hline \multirow[t]{3}{*}{ BM-B } & $\begin{array}{l}\text { Barley } \\
\text { (Chacha) }\end{array}$ & 32 & $27 / 12 / 12$ & 100 & $23 / 04 / 13$ & $13 / 05 / 13$ & 150.0 & 15.0 & 20.0 & $20 / 06 / 13$ \\
\hline & $\begin{array}{c}\text { Maize } \\
(D K 4795)\end{array}$ & 32 & $09 / 07 / 13$ & 427 & $11 / 07 / 13$ & $13 / 10 / 13$ & 285.5 & 45.0 & 22.5 & $25 / 11 / 13$ \\
\hline & $\begin{array}{l}\text { Barley } \\
\text { (Chacha) }\end{array}$ & 32 & $20 / 12 / 13$ & 66 & $21 / 12 / 13$ & $10 / 05 / 14$ & 155.0 & 20.0 & 25.0 & $02 / 06 / 14$ \\
\hline \multirow[t]{3}{*}{ S-BM } & $\begin{array}{l}\text { Sunflower } \\
(P R 64 A 14)\end{array}$ & 18.5 & $23 / 04 / 13$ & 447 & $02 / 05 / 13$ & $28 / 08 / 13$ & 131.0 & 47.0 & 67.0 & $25 / 09 / 13$ \\
\hline & $\begin{array}{l}\text { Barley } \\
\text { (Chacha) }\end{array}$ & 18.5 & $02 / 12 / 13$ & 34 & $06 / 03 / 14$ & $17 / 04 / 14$ & 92.7 & 33.0 & 0.0 & $11 / 06 / 14$ \\
\hline & $\begin{array}{c}\text { Maize } \\
\text { (Lambada) }\end{array}$ & 18.5 & $21 / 06 / 14$ & 439 & $22 / 06 / 14$ & $03 / 10 / 14$ & 168.4 & 66.8 & 110.2 & $17 / 12 / 14$ \\
\hline
\end{tabular}

M-M - maize monoculture; BM-B - barley+maize-barley rotation; S-BM - sunflower-barley+maize rotation; IW - seasonal irrigation water applied; $\mathrm{N}$ - applied nitrogen; $\mathrm{P}$ - applied phosphorus; $\mathrm{K}$ - applied potassium. 
Table 4. Seasonal crop evapotranspiration and precipitation

\begin{tabular}{ccc}
$\begin{array}{c}\text { Cropping } \\
\text { system }\end{array}$ & ETc $(\mathbf{m m})$ & $\mathbf{P}(\mathbf{m m})$ \\
\hline M-M & 669.6 & 25.4 \\
\cline { 2 - 3 } & 653.1 & 51.8 \\
\hline BM-B & 385.0 & 262.7 \\
\cline { 2 - 3 } & 398.7 & 67.7 \\
\hline S-BM & 396.8 & 299.6 \\
\cline { 2 - 3 } & 534.8 & 14.5 \\
\hline & 336.2 & 271.2 \\
\hline
\end{tabular}

ETc - seasonal crop evapotranspiration; P - seasonal precipitation.

2006; Albrizio et al. 2010; Pereira et al. 2012): (i) Water Use Efficiency (WUE) $\left(\mathrm{kg} / \mathrm{m}^{3}\right), W U E=Y /$ $E T c$, where $Y$ is the grain yield $(\mathrm{kg} / \mathrm{ha})$ and $E T c$ is the crop evapotranspiration ( $\mathrm{m}^{3} / \mathrm{ha}$ ); (ii) Irrigation Water Use Efficiency (IRRWUE) estimated by IRRWUE $=Y / I W$, where $I W$ is the seasonal irrigation water applied ( $\left.\mathrm{m}^{3} / \mathrm{ha}\right)$.

The following relationships were considered in the determination of nutrient use efficiency (Pikul et al. 2005; Di Paolo and Rinaldi 2008; Albrizio et al. 2010; Fixen et al. 2015): (i) Nitrogen Use Efficiency $(\mathrm{kg} / \mathrm{kg}), N U E_{N}=Y / A N$, where $A N$ is the available $N(\mathrm{~kg} / \mathrm{ha})$ resulting from sources in the mineral form by application of fertilizers, not considering the quantities of $\mathrm{N}$ that can be released by mineralization of organic matter $(\mathrm{OM})$, with the exception of cases where OM is greater than $25 \mathrm{~g} / \mathrm{kg}$, following the Portuguese government recommendation on the protection of waters against pollution caused by nitrates from agricultural sources (Diário da República, Portaria $n^{\circ}$ 259/2012); (ii) Phosphorus Use Efficiency $(\mathrm{kg} / \mathrm{kg}), N U E_{P}=Y / A P$, where $A P$ is the available phosphorus ( $\mathrm{kg} \mathrm{P}_{2} \mathrm{O}_{5} / \mathrm{ha}$ ), including phosphorous from mineral fertilization and the extractable phosphorous content in soil; (iii) Potassium Use Efficiency $\left(\mathrm{NUE}_{\mathrm{K}}\right)(\mathrm{kg} / \mathrm{kg})$, $N U E_{K}=Y / A K$, where $A K$ is the available potassium ( $\mathrm{kg} \mathrm{K} \mathrm{K}_{2} \mathrm{O} / \mathrm{ha}$ ), including potassium from mineral fertilization and the extractable potassium content in soil.
In calculating the amount of nitrogen available by mineralization of soil OM, a $5 \%$ content of nitrogen in OM, mineralized at a $1.5 \%$ rate over the crop cycle (Quelhas dos Santos 1996) was considered.

To determine extractable phosphorus and potassium, the retention rates of these nutrients that may occur in soil were taken into account - $80 \%$ for phosphorus and $55 \%$ for potassium. In fine textured soils, like the ones of the plots under study, a strong retention of phosphorus is expected, while the availability of potassium is affected by adsorption or by fixation on the clay minerals (Quelhas dos Santos 1996; Varennes 2003).

\section{Results}

\subsection{Soil fertility}

The evolution of the soil fertility parameters throughout the study period is summarized in Table 5. In the M-M cropping system (whose antecedent crop was maize) there was variation in the soil reaction. In the BM-B rotation (whose antecedent crop was sunflower) all parameters changed. In the S-BM rotation (whose 
antecedent crop was soft wheat) there was a more important variation in two of the quantified parameters, namely the total soil OM content and the soil reaction.

3.2. Yield, water use efficiency and nutrients use efficiency

Grain yield values reflect more the crop cycle length than the crop succession (Table 6), especially in the case of maize, where the highest yields were observed in the M-M succession.
Maize had the highest values of WUE and sunflower the lowest. As for IRRWUE, barley presented the highest values due to low irrigation water inputs. In contrast, the lowest values were found in maize and in sunflower, both SpringSummer thus dry season crops.

In general, the NUE values were higher in the M-M cropping system, with the lowest values occurring in the S-BM rotation, mainly reflecting the yields obtained in the sunflower and maize crops.

Table 5. Soil fertility parameters in the beginning of the experiment and throughout the study period

\begin{tabular}{|c|c|c|c|c|c|}
\hline $\begin{array}{l}\text { Cropping } \\
\text { system }\end{array}$ & $\begin{array}{l}\text { Crop } \\
\text { (year) }\end{array}$ & OM $(g / k g)^{*}$ & $\begin{array}{c}\mathrm{pH}\left(\mathrm{H}_{2} \mathrm{O}\right) \\
\text { (Classification) }\end{array}$ & $\begin{array}{c}\mathrm{P}_{2} \mathrm{O}_{5} \\
(\mathrm{mg} / \mathrm{kg})^{*}\end{array}$ & $\begin{array}{c}\mathrm{K}_{2} \mathrm{O} \\
(\mathrm{mg} / \mathrm{kg})^{*}\end{array}$ \\
\hline & $\begin{array}{l}\text { Maize } \\
(2012)\end{array}$ & $12(\mathrm{~L})$ & $\begin{array}{l}8.4 \text { (Slightly } \\
\text { alkaline) }\end{array}$ & $195(\mathrm{H})$ & $412(\mathrm{VH})$ \\
\hline \multirow[t]{3}{*}{ M-M } & $\begin{array}{l}\text { Maize } \\
(2013)\end{array}$ & $19(\mathrm{~L})$ & 7.5 (Neutral) & $150(\mathrm{H}) \mathrm{o}$ & $347(\mathrm{VH})$ \\
\hline & $\begin{array}{l}\text { Maize } \\
(2014)\end{array}$ & $12(\mathrm{~L})$ & Neutral & $95(\mathrm{M})$ & $208(\mathrm{VH})$ \\
\hline & $\begin{array}{l}\text { Sunflower } \\
\text { (2012) }\end{array}$ & $10(\mathrm{VL})$ & $\begin{array}{l}8.4 \text { (Slightly } \\
\text { alkaline) }\end{array}$ & $82(M)$ & $190(\mathrm{H})$ \\
\hline \multirow[t]{4}{*}{ BM-B } & $\begin{array}{l}\text { Barley } \\
(2013)\end{array}$ & $7(\mathrm{VL})$ & $\begin{array}{l}8.5 \text { (Slightly } \\
\text { alkaline) }\end{array}$ & $82(\mathrm{M})$ & $170(\mathrm{H})$ \\
\hline & $\begin{array}{l}\text { Maize } \\
(2013)\end{array}$ & $16(\mathrm{~L})$ & 7.3 (Neutral) & $219(\mathrm{VH})$ & $452(\mathrm{VH})$ \\
\hline & $\begin{array}{l}\text { Barley } \\
(2014)\end{array}$ & $21(\mathrm{M})$ & 7.5 (Neutral) & $132(\mathrm{H})$ & $278(\mathrm{VH})$ \\
\hline & $\begin{array}{l}\text { Wheat } \\
(2012)\end{array}$ & $14(\mathrm{~L})$ & $\begin{array}{l}8.5 \text { (Slightly } \\
\text { alkaline) }\end{array}$ & $68(M)$ & $160(H)$ \\
\hline \multirow[t]{3}{*}{ S-BM } & $\begin{array}{l}\text { Sunflower } \\
\text { (2013) }\end{array}$ & $31(\mathrm{M})$ & 6.9 (Neutral) & $79(\mathrm{M})$ & $163(H)$ \\
\hline & $\begin{array}{l}\text { Barley } \\
(2014)\end{array}$ & $39(\mathrm{M})$ & $\begin{array}{l}6.5 \text { (Slightly } \\
\text { acid) }\end{array}$ & $101(H)$ & $242(\mathrm{VH})$ \\
\hline & $\begin{array}{l}\text { Maize } \\
(2014)\end{array}$ & 34 (M) & 7.1 (Neutral) & $82(M)$ & $190(\mathrm{H})$ \\
\hline
\end{tabular}

M-M - maize monoculture; BM-B - barley+maize-barley rotation; S-BM - sunflower-barley+maize rotation; OM - organic matter; $\mathrm{P}_{2} \mathrm{O}_{5}$ - extractable phosphorus, in phosphorus oxide form; $\mathrm{K}_{2} \mathrm{O}$ - extractable potassium, in potassium oxide form. *Letters between brackets refer to the parameter value classification according to the method of determination used: VL - Very Low; L - Low; M - Medium; H - High; VH - Very High. Values in the shaded lines refer to the antecedent crops, in the beginning of the study. 
Table 6. Grain yield, water use efficiency (WUE), irrigation water use efficiency (IRRWUE), nitrogen use efficiency $\left(\mathrm{NUE}_{\mathrm{N}}\right)$, phosphorus use efficiency $\left(\mathrm{NUE}_{\mathrm{p}}\right)$, and potassium use efficiency $\left(\mathrm{NUE}_{\mathrm{K}}\right)$

\begin{tabular}{|c|c|c|c|c|c|c|c|}
\hline $\begin{array}{l}\text { Cropping } \\
\text { system }\end{array}$ & $\begin{array}{l}\text { Crop } \\
\text { (year) }\end{array}$ & $\begin{array}{l}\text { Grain } \\
\text { yield } \\
\text { (kg/ha) }\end{array}$ & $\begin{array}{l}\text { WUE } \\
\left(\mathrm{kg} / \mathrm{m}^{3}\right)\end{array}$ & $\begin{array}{l}\text { IRRWUE } \\
\left(\mathrm{kg} / \mathrm{m}^{3}\right)\end{array}$ & $\begin{array}{c}\mathrm{NUE}_{\mathrm{N}} \\
(\mathrm{kg} / \mathrm{kg} \mathrm{N})\end{array}$ & $\begin{array}{c}\text { NUE }_{\mathrm{p}} \\
\left(\mathrm{kg} / \mathrm{Kg} \mathrm{P} \mathrm{P}_{2} \mathrm{O}_{5}\right)\end{array}$ & $\begin{array}{c}\mathrm{NUE}_{\mathrm{K}} \\
\left(\mathrm{kg} / \mathrm{kg} \mathrm{K} \mathrm{K}_{2} \mathrm{O}\right)\end{array}$ \\
\hline \multirow[t]{2}{*}{ M-M } & $\begin{array}{l}\text { Maize } \\
(2013)\end{array}$ & 15000 & 2.2 & 2.2 & 41.7 & 81.7 & 24.5 \\
\hline & $\begin{array}{l}\text { Maize } \\
(2014)\end{array}$ & 17000 & 2.6 & 2.7 & 47.3 & 112.6 & 39.8 \\
\hline \multirow[t]{3}{*}{ BM-B } & $\begin{array}{l}\text { Barley } \\
(2013)\end{array}$ & 5078 & 1.3 & 5.1 & 33.9 & 81.9 & 21.2 \\
\hline & $\begin{array}{l}\text { Maize } \\
(2013)\end{array}$ & 10700 & 2.7 & 2.5 & 37.5 & 62.7 & 17.7 \\
\hline & $\begin{array}{l}\text { Barley } \\
(2014)\end{array}$ & 4900 & 1.2 & 7.4 & 31.6 & 51.2 & 12.8 \\
\hline \multirow[t]{3}{*}{ S-BM } & $\begin{array}{l}\text { Sunflower } \\
(2013)\end{array}$ & 2544 & 0.5 & 0.6 & 15.6 & 28.3 & 9.5 \\
\hline & $\begin{array}{l}\text { Barley } \\
(2014)\end{array}$ & 4265 & 1.3 & 12.4 & 32.2 & 48.5 & 14.4 \\
\hline & $\begin{array}{l}\text { Maize } \\
(2014)\end{array}$ & 4370 & 1.0 & 1.0 & 23.5 & 39.2 & 12.7 \\
\hline
\end{tabular}

MM - maize monoculture; BM-B - rotation barley+maize-barley; S-BM - rotation sunflower-barley+maize.

\section{Discussion}

At the end of the study, soil $\mathrm{pH}$ decreased and was classified as neutral in each of the cropping systems, suggesting that the final balance between proton entrances and exits in the soil was favorable to a greater proton input (Table 5). Among the agronomic management practices used, the application of fertilizers may have been one of the factors that contributed to this result.

The total soil OM content of both crop rotations increased, contrary to what happened in the maize continuous crop. The fact that there was no change in the total soil OM content in the M-M cropping system suggests that the losses of OM by the microorganisms activity were balanced by the additions resulting from the vegetal residues. Comparing the two rotations, the BM-B rotation, with higher yields, registered a larger increase of the total OM soil content. In fact, high yields associated with no tillage practices contribute to the soil enrichment in OM. As for extractable phosphorus and potassium, high levels of phosphorus (M-M, BM-B) and potassium (S-BM) and very high levels of potassium (M-M, BM-B) are results that can influence future fertilizer applications, and can be positively reflected on both the soil quality and on-farm resources allocation.

It was the duration of the growing season, rather than the crop succession, that contributed to the maize yield differentiation (Table 6). In fact, the highest yields were observed in the maize monoculture, $M-M$, where maize crop development cycles were longer. The low productivity of maize grown in the S-BM rotation was the result of a strong attack of the Mediterranean corn borer (Sesamia nonagrioides Lefèvre). There were also problems in its implementation as a second crop after barley, related to post-emergence weed control (monocotyledonous), as well as to the harvest date due to the occurrence of a long rainy period following the physiological maturity stage. The sunflower yield could have been higher but an excessive plant population may have promoted competition between plants, translated into small capitula with few achenes. Barley yields in the different rotations and years 
were similar, with the lowest value observed in the S-BM rotation, probably due to the low water supply.

The values of WUE and IRRWUE in maize, barley and sunflower were close, or higher in the case of maize, to those referred in other studies carried in similar climates (Table 7), indicating high crop productivity per each drop of water used. The exception occurred in the maize of S-BM rotation, where low WUE was due to a low grain yield, and thus far-removed from the crop potential yield.

Given the distinct dry season prevailing in Mediterranean climates, the rainfall contribution to the water requirements of Spring-Summer crops is very low. Therefore, the IRRWUE values found for maize and sunflower did not differ from the WUE values. Differences between IW (Table 3) and ETc (Table 4) for barley are due to the availability of water provided by rainfall in the Autumn-Winter period that ensures that the crop water requirements are met with little addition of irrigation water. Thus, there are considerable differences between the IRRWUE and WUE values found for barley, a crop whose cycle takes place in the rainy season, hence with low irrigation water inputs. This is because crop yields depend not only on the amount of irrigation water applied but also on the effective rainfall, which in turn is dependent on the rainfall distribution during the crop development cycle (Pereira et al. 2012).

When the potential yield of the crop was reached, maize presented higher WUE values compared to barley and sunflower. This can be explained by relating the agronomic and ecophysiological resource-use efficiencies. Different crops have different efficiencies in terms of the relationship between biomass or grain produced and water use, also as a result of their carbon assimilation mechanisms: C4 species as maize are more efficient in using water than C3 species such as barley or sunflower (Hay and Walker 1989; Sharma et al. 2015). In overall terms, and considering these aspects, the water productivity indicators point to a good yield water use efficiency of the M-M and BM-B cropping systems and a less balanced performance of the S-BM rotation.

Table 7. Some WUE and IRRWUE values found in literature

\begin{tabular}{|c|c|c|c|c|}
\hline Crop & $\begin{array}{l}\text { WUE } \\
\left(\mathrm{kg} / \mathrm{m}^{3}\right)\end{array}$ & $\begin{array}{l}\text { IRRWUE } \\
\left(\mathbf{k g} / \mathrm{m}^{3}\right)\end{array}$ & Reference & Notes \\
\hline \multirow[t]{4}{*}{ Maize } & $1.9-2.2$ & - & $\begin{array}{l}\text { Pikul et al. } \\
\text { (2005) }\end{array}$ & $\begin{array}{l}\text { Lowest and highest values refer to 2-year } \\
\text { continuous maize and 2-year Maize- } \\
\text { Soybean rotation, respectively. }\end{array}$ \\
\hline & $1.6-2.1$ & $2.4-2.9$ & $\begin{array}{l}\text { Dağdelen et al. } \\
\text { (2006) }\end{array}$ & Lowest value refers to rainfed treatment. \\
\hline & $1.4-2.2$ & $2.3-3.3$ & $\begin{array}{l}\text { Di Paolo and } \\
\text { Rossi (2008) }\end{array}$ & $\begin{array}{l}\text { Lowest and highest values refer to rainfed } \\
\text { treatment and } 300 \mathrm{~kg}(\mathrm{~N}) / \text { ha level of nitro- } \\
\text { gen fertilization, respectively. }\end{array}$ \\
\hline & $2.9-3.2$ & - & $\begin{array}{l}\text { Kresović et al. } \\
(2016)\end{array}$ & $\begin{array}{l}\text { Lowest and highest values refer to rainfed } \\
\text { treatment and } 50 \% \text { ETc level of irriga- } \\
\text { tion, respectively, in a humid sub-tropical } \\
\text { climate. }\end{array}$ \\
\hline \multirow[t]{2}{*}{ Barley } & 1.4 & - & $\begin{array}{l}\text { Albrizio et al. } \\
\text { (2010) }\end{array}$ & \\
\hline & $0.1-1.0$ & - & $\begin{array}{l}\text { Morell et al. } \\
(2011)\end{array}$ & $\begin{array}{l}\text { Lowest value obtained with conventional } \\
\text { tillage and } 120 \mathrm{~kg}(\mathrm{~N}) / \mathrm{ha} \text { of nitrogen ferti- } \\
\text { lization. Highest value refers to no-tillage } \\
\text { and } 60 \mathrm{~kg}(\mathrm{~N}) / \mathrm{ha} \text { of nitrogen fertilization. }\end{array}$ \\
\hline \multirow[t]{2}{*}{ Sunflower } & 0.7 & - & $\begin{array}{l}\text { Langeroodi et } \\
\text { al. (2014) }\end{array}$ & \\
\hline & 0.5 & - & $\begin{array}{l}\text { Howell et al. } \\
\text { (2015) }\end{array}$ & \\
\hline
\end{tabular}

WUE - water use efficiency; IRRWUE - irrigation water use efficiency. 
The WUE and $\mathrm{NUE}_{\mathrm{N}}$ values in the various crops and rotations follow a similar pattern evidencing how yield responses to nitrogen fertilization interact with water availability. The M-M cropping system presented the highest $\mathrm{NUE}_{\mathrm{N}}$. The lowest $\mathrm{NUE}_{\mathrm{N}}$ occurred in the S-BM rotation, mainly reflecting the low yields, but also a reduced effectiveness in the use of the available nitrogen resulting from fertilization and mineralization of the soil OM, according to the adopted methodology of calculation of available $\mathrm{N}$. The comparison of $\mathrm{NUE}_{\mathrm{N}}$ values referred in literature with those obtained in our study for maize suggests that these were within the expected range and in some cases even higher (Table 8). Taking into account the $\mathrm{NUE}_{\mathrm{N}}$ referenced in other studies, barley and sunflower were inefficient in the use of available nitrogen. However, the value of this indicator for the sunflower crop in our study probably reflects its low yield rather than utilization of the available nitrogen.

The $\mathrm{NUE}_{\mathrm{p}}$ values obtained are, in almost all crops, within the average range reported for crops in general (Table 8). Again, the exceptions are sunflower and maize in the S-BM rotation, with lower values. These results show that whenever the crop potential yield was reached, not being affected by water stress, phytosanitary problems or factors resulting from less adjusted agronomic practices, the studied cropping systems and the crops they included were efficient in the use of this nutrient. The high $\mathrm{NUE}_{\mathrm{p}}$ value of the maize grown in monoculture in 2014 was due to both the high yield and the low availability of soil extractable phosphorus. This result shows that the crop very effectively used the phosphorous made available by mineral fertilization, which evidences the importance of accounting for soil extractable phosphorus in fertilization recommendations.

The NUE $_{K}$ values were low in all the studied crops, considering the average range of $\mathrm{NUE}_{\mathrm{K}}$ values for crops in general (Table 8). However, this range of values only includes potassium availability conveyed by fertilizer additions, not considering potassium availability in the soil. In addition to the expected values in the S-BM rotation, due to the low yields obtained in sunflower and maize, these results also suggest that potassium fertilizations could have been lower without the risk of compromising the expected yields or affecting the maintenance of soil fertility. Maize was the most efficient crop using potassium, a parallel result to the ones obtained for the other nutrients use efficiency indicators in this crop.

In general, the M-M and BM-B cropping systems presented the best indicators of nutrients use efficiency, mainly for nitrogen and phosphorus.

Table 8. Some $\mathrm{NUE}_{\mathrm{N}}, \mathrm{NUE}_{\mathrm{P}}$ and $\mathrm{NUE}_{\mathrm{K}}$ values found in literature

\begin{tabular}{|c|c|c|c|c|c|}
\hline Crop & $\begin{array}{c}\operatorname{NUE}_{\mathrm{N}} \\
(\mathbf{k g} / \mathbf{k g} \mathbf{N})\end{array}$ & $\begin{array}{c}\text { NUE }_{\mathrm{p}} \\
\left(\mathrm{kg} / \mathrm{kg} \mathrm{P_{2 }} \mathrm{O}_{5}\right)\end{array}$ & $\begin{array}{c}\mathrm{NUE}_{\mathrm{K}} \\
\left(\mathrm{kg} / \mathrm{kg} \mathrm{K}_{2} \mathrm{O}\right)\end{array}$ & Reference & Notes \\
\hline \multirow[t]{2}{*}{ Maize } & $35.0-43.0$ & - & - & $\begin{array}{l}\text { Pikul et al. } \\
\text { (2005) }\end{array}$ & $\begin{array}{l}\text { Lowest and highest values refer to 2-year } \\
\text { continuous maize and 2-year Maize- } \\
\text { Soybean rotation, respectively. }\end{array}$ \\
\hline & $9.9-36.7$ & - & - & $\begin{array}{l}\text { Di Paolo and } \\
\text { Rossi (2008) }\end{array}$ & $\begin{array}{l}\text { Lowest and highest values refer to rainfed } \\
\text { treatment and } 100 \% \text { ETc level of irrigation, } \\
\text { respectively. }\end{array}$ \\
\hline Barley & 53.3 & - & - & $\begin{array}{l}\text { Albrizio et al. } \\
(2010)\end{array}$ & \\
\hline $\begin{array}{l}\text { Crops in } \\
\text { general }\end{array}$ & $40.0-90.0$ & $45.0-110.0$ & $60.0-165.0$ & $\begin{array}{l}\text { Fixen et al. } \\
(2015)\end{array}$ & \\
\hline
\end{tabular}

$\mathrm{NUE}_{N}$ - nitrogen use efficiency; $\mathrm{NUE}_{\mathrm{P}}$ - phosphorus use efficiency; $\mathrm{NUE}_{K}$ - potassium use efficiency. 


\section{Conclusions}

Contrary to whathappened in the maize continuous crop, the total organic matter content increased in the crop rotations. The final balance of extractable $\mathrm{P}$ and $\mathrm{K}$ contents was positive in the BM-B rotation, evidencing that the fertilization applications of these nutrients exceeded the exports of the crops. More than the type of cropping system, it was the duration of the growing season that contributed to the maize productivity. The highest yields were observed in the M-M cropping system, with longer development cycles. Compared to barley and sunflower, maize showed higher WUE values. Also, maize WUE and IRRWUE were higher than some values found in the literature, indicating high water productivity.

In general, the WUE values obtained point to a less balanced performance of the S-BM rotation. The M-M and BM-B cropping systems presented the best indicators of nutrient use efficiency, mainly nitrogen and phosphorus. However, the potassium use efficiency of all crops was low, evidencing the need to carefully consider the additions of this nutrient by fertilization.

\section{Acknowledgements}

This work was supported by PRODER, Programa de Desenvolvimento Rural, through the Project ROTALQ - Soluções integradas de rotações culturais com viabilidade técnica e económica na área de influência do Alqueva. This work is a contribution to the Project UID/ GEO/04035/2013, funded by FCT - Fundação para a Ciência e a Tecnologia, Portugal.

\section{REFERENCES}

- Albrizio R, Todorovic M, Matic T, Stellacci AM. 2010. Comparing the interactive effects of water and nitrogen on durum wheat and barley grown in a Mediterranean environment. Field Crops Res. 115:179-190.

- Allen RG, Pereira LS, Raes M, Smith M. 1998. Crop evapotranspiration guidelines for computing water requirements. FAO Irrigation and Drain Paper No. 56. Rome: FAO.

- COTR. 2016a. [Internet]. Centro Operativo e de Tecnologia de Regadio: SAGRA - Sistema Agrometeorológico para a Gestão da Rega no Alentejo [cited 2016 Mar 31]. Available from: http://www.cotr.pt/ cotr/sagra.asp.

- COTR. 2016b. [Internet]. Centro Operativo e de Tecnologia de Regadio: MOGRA - Modelo de Gestão da Rega para o Alentejo [cited 2015 Jan 3]. Available from: http://www.cotr.pt/cotr/sagra_II/.

- Dağdelen N, Yilmaz E, Sezgin F, Gürbüz T. 2006. Water-yield relation and water use efficiency of cotton (Gossypium hirsutum L.) and second crop corn (Zea mays L.) in western Turkey. Agric Water Manag. 82:6385. doi:10.1016/j.agwat.2005.05.006.

- Di Paolo E, Rinaldi M. 2008. Yield response of corn to irrigation and nitrogen fertilization in a Mediterranean environment. Field Crops Res. 105:202-210.

- Diário da República, Portaria n. ${ }^{\circ} 259 / 2012$ de 28 de agosto. $1 .^{a}$ série - N. ${ }^{\circ} 166-28$ de agosto de 2012.

- Egner H, Riehm H, Domingo WR. 1960. Untersuchhungen uber die chemische boden: Analyse als grundlage fur die beurteilung der nahrstoffzustandes der boden. II. Chemique extractions, methoden zur phosphor, und kalium-bestimmung. Kungl Lantbrukshoegsk Ann. 26:199-215.

- Eltz FLF, Norton LD. 1997. Surface roughness changes as affected by rainfall erosivity, tillage and canopy cover. Soil Sci. 61:1746-1754.

- Eurostat. 2017 [Internet]. Crop statistics (from 2000 onwards). [cited 2017 Oct 24]. Available from: http:/l appsso.eurostat.ec.europa.eu/.

- Fixen P, Brentrup F, Bruulsema TW, García F, Norton R, Zingore S. 2015. Nutrient/fertilizer use efficiency: measurement, current situation and trends. In: Drechsel $\mathrm{P}$, Heffner P, Magen H, Mikkelsen R, Wichelns D, editors. Managing Water and Fertilizer for Sustainable Agricultural Intensification. Paris: IFA, IWMI, IPNI, IPI. p. 8-38.

- Grzebisz W, Gransee A, Szczepaniak W, Diatta J. 2013. The effects of potassium on water-use efficiency in crop plants. J Plant Nutr Soil Sci. 176:355-374.

- Hay RKM, Walker AJ. 1989. An introduction to the physiology of crop yield. Longman Scientific \& Technical. New York: John Wiley \& Sons, Inc. 
- Hernández M, Echarte L, Della Maggiora A, Cambareri M, Barbieri P, Cerrudo D. 2015. Maize water use efficiency and evapotranspiration response to $\mathrm{N}$ supply under contrasting soil water availability. Field Crops Res. 178:8-15. Available from: http://dx.doi.org/10.1016/j. fcr.2015.03.017.

- Howell TA. 2001. Enhancing water use efficiency in irrigated agriculture. Agron J. 93:281-289.

- Howell TA, Evett SR, Tolk JA, Copeland KS, Marek TH. 2015. Evapotranspiration, water productivity and crop coefficients for irrigated sunflower in the U.S. Southern High Plains. Agric Water Manag. 162:33-46. Available from: http://dx.doi.org/10.1016/j.agwat.2015.08.008.

- INE. 2017. Estatísticas Agrícolas 2016. Lisboa, Portugal: Instituto Nacional de Estatística, IP.

- IPMA. 2016. [Internet]. Instituto Português do Mar e da Atmosfera: Normais climatológicas 1981-2010 provisórias de Beja [cited 4 March 2016]. Available from: https://www. ipma.pt/pt/oclima/normais.clima/1981-2010/002/.

- IUSS Working Group WRB. 2015. World Reference Base for Soil Resources 2014, Update 2015. International soil classification system for naming soils and creating legends for soil maps. World Soil Resources Report No. 106. Rome: FAO.

- Kresović B, Tapanarova A, Tomić Z, Životić L, Vujović D, Sredojević Z, Gajić B. 2016. Grain yield and water use efficiency of maize as influenced by different irrigation regimes through sprinkler irrigation under temperate climate. Agric Water Manag. 169:34-43. Available from: https://doi.org/10.1016/j.agwat.2016.01.023.

- Langeroodi ARS, KamKar B, Teixeira da Silva JA, Ataei M. 2014. Response of sunflower cultivars to deficit irrigation. HELIA 37(60):37-58.

- López-Fando C, Almendros G. 1995. Interactive effects of tillage and crop rotations on yield and chemical properties of soils in semi-arid Central Spain. Soil Till Res. 36:45-57.

- Mendes J, Boteta L, Santos M, Varela M, Brás P, Silvestre J. 2014. Rega. Chapter 7. In: Jordão P, editor. Boas práticas no olival e no lagar. Instituto Nacional de Investigação Agrária e Veterinária, IP. p. 178-220.

- Morell FJ, Lampurlanés J, Álvaro-Fuentes J, CanteroMartínez C. 2011. Yield and water use efficiency of barley in a semiarid Mediterranean agroecosystem: Long-term effects of tillage and N fertilization. Soil Till Res. 117:7684.

- Nevens F, Reheul D. 2001. Crop rotation versus monoculture: Yield, $\mathrm{N}$ yield and ear fraction of sillage maize at different levels of mineral $\mathrm{N}$ fertilization. Netherlands J Agric Sci. 49:405-425.

- Pereira LS, Cordery I, lacovides I. 2012. Improved indicators of water use performance and productivity for sustainable water conservation and saving. Agric Water Manag. 108:39-51.

- Pikul JL, HaM-Mack L, Riedell W. 2005. Corn yield, nitrogen use, and corn rootworm infestation of rotations in the Northern Corn Belt. Agron J. 97:854-863.
- Quelhas dos Santos J. 1996. Fertilização. Fundamentos da utilização de adubos e correctivos. $2^{\mathrm{a}}$ Ed. Colecção Euroagro. Mem Martins: Publicações Europa-América.

- Sainju UM, Lenssen AW, Caesar-Tonthat T, Jabro JD, Lartey RT, Evans RG, Allen BL. 2011. Dryland residue and soil organic matter as influenced by tillage, crop rotation, and cultural practices. Plant Soil 338:27-41.

- Sharma B, Molden D, Cook S. 2015. Water use efficiency in agriculture: measurement, current situation and trends. In: Drechsel P, Heffner P, Magen H, Mikkelsen $\mathrm{R}$, Wichelns $\mathrm{D}$, editors. Managing Water and Fertilizer for Sustainable Agricultural Intensification. Paris: IFA, IWMI, IPNI, IPI. p. 39-64

- Varennes A. 2003. Produtividade dos solos e ambiente. Lisboa: Escolar Editora.

- Walkley A, Black LA. 1934. An examination of the Dgtjareff method for determining soil organic matter, and a proposed modification of the chromic acid titration method. Soil Sci. 37:29-38

- Zwart SJ, Bastiaanssen WGM. 2004. Review of measured crop water productivity values for irrigated wheat, rice, cotton and maize. Agric Water Manag. 69:115-133. doi:10.1016/j.agwat.2004.04.007. 